\title{
The Mathematical Gazette: a brief history
}

\section{MIKE DAMPIER}

'One morning in May 1894 we were all sitting hard at work, and directly Levett came into the room he walked round and gave each of us a copy of the first number of a new periodical called The Mathematical Gazette.'

So wrote Arthur Siddons (1876-1959) recalling his school-days at King Edward School, Birmingham [1]. It was from that school that the mathematics master, Rawdon Levett, in 1870 had written a letter to Nature [2] proposing an 'Anti-Euclid Association' aiming, amongst other things, 'to induce examining bodies to frame their questions in geometry without reference to any particular textbook'. As a result of that letter the Mathematical Association came into existence, although it was to be twentyfive years before it acquired that name [3]. At first the Association for the Improvement of Geometrical Teaching, as the new organisation was originally called, acted as a pressure group and only gradually did it move to become a wider teaching association. The founding of the Mathematical Gazette in 1894 marks a decisive stage in that movement.

The creator of the Gazette was E.M. Langley (1851-1933); he was its first editor and contributed its first article 'The eccentric circle of Boscovich'. Langley, who for over fifty years was associated with Bedford Modern School, had first looked across the Channel for a model, intending to produce something on the lines of $\mathrm{H}$. Vuibert's Journal de Mathé matique Elé mé ntaires. This journal, published in Paris from 1877, was directed at schoolboys preparing for the public examinations for the Ecole Polytechnique and similar colleges, and gave most of its space to questions and their solutions. Levett obviously assumed the new Gazette would be read by schoolboys but, in fact, it was always unlikely that the journal should be like Vuibert's, for nothing in England quite matched the competitive examinations of France and in addition there was already an English journal, the Educational Times, publishing mathematical problems and solutions. But probably more decisive was the audience; Vuibert could profitably address schoolboys, but the Gazette grew out of an existing association of teachers and had to meet their desire to be in contact and to learn from each other. This pre-existing audience enabled the Gazette to grow but it was also a source of tension - was it to be primarily a mathematical journal or primarily a newsletter of a professional association? Langley adopted a pragmatic approach, writing on the front of his first issue 'Our course must be tentative. We must find out from our readers on which of several possible lines it is best .... to proceed.' He announced a definite intention to keep strictly to 'elementary mathematics' which he explained would normally exclude the Calculus. Pressure of schoolwork, however, coupled with ill-health forced Langley's early resignation as editor, and members of the association were circulated to see whether they wanted the 
journal to continue. They did; and from 1896 F. S. Macaulay (1862-1937) took over as editor. He always considered his to be an interim appointment, but nevertheless saw through decisive changes that in many ways created the shape of the Gazette in the twentieth century.

He changed the size from quarto to the familiar octavo and considerably widened the scope of the journal. It was to contain 'articles and notes on the science, history and teaching of elementary mathematics, problems within the range of Open Scholarships at the Universities, correspondence, items of news, requests for information, notices of new mathematics textbooks and solutions to some of the questions'. It was the introduction of reviews perhaps more than anything else which secured the reputation of the Gazette amongst university mathematicians and created the breadth of readership that stood it in such good stead in future years. Macaulay was for twentyfive years from 1885 a teacher at St Paul's School. His most famous pupil, J. E. Littlewood, said of him, 'He was as independent in his teaching as in his original work'. This original work - he was a pioneer in England of what is now called commutative algebra - led to his election as FRS in 1928.

The real driving force, however, behind the success of the Gazette was W. J. Greenstreet (1861-1930), who became editor in 1899. He held the post until his death in 1930 and made the Gazette into what was described as 'the most readable and interesting of all mathematical journals'. Greenstreet, the son of a sergeant-major in the army, was at Cambridge with Macaulay, but a combination of problems connected with his eyesight and financial difficulties prevented him achieving a good degree. In 1882 he became a teacher at the Marling School, Stroud and in time became headmaster. But in 1911, after a disagreement with the governors, he resigned and devoted himself to literary and scientific work. Later he was to give much time to the training of young pupil teachers in the Reading area.

Greenstreet took over the editorship at the beginning of a time of profound change in English mathematical education. The reform movement associated with the name of Professor Perry quickened the pulse of the teaching community and brought many new members into the MA. The Gazette had to address their interest if it was to prosper. Greenstreet's first step was a gamble; he doubled the number of issues to six a year. This would, of course, greatly increase in readers the sense of being in touch with their association, but it was financially risky and soon the association had to raise their annual subscription from seven shillings and sixpence to ten shillings to help cover costs, and in 1902 the price of a single issue to nonmembers rose from one shilling to one shilling and sixpence. But Greenstreet had judged correctly, and although there probably were grumblers, members and subscribers were prepared to pay the new prices. The three issues in 1899 together had contained 82 pages, but by 1907 this yearly total was 168 pages, whilst by 1914 it had reached over 200 pages. From the editor's point of view the increased space meant that the journal could find room for association business and, later, pedagogic articles 
without ceasing to be a mathematical journal.

The next change was in the problems and solutions department, the classic matter of an elementary journal. In 1901 Greenstreet announced that 'owing to space no more problems will appear until the solutions of nos. 1 449 are complete', and after the middle of 1904 the section disappeared completely, except for three issues in 1907 and 1908 which were wholly given over to solutions of nearly all the outstanding problems. With those issues the department seemed definitively closed, and an attempt between the wars to reopen it came to nothing. Greenstreet must have judged, correctly it seems, that the new schoolteacher reader simply did not have time to spend on what one called 'recondite conundrums'. Here is an example from 1895 .

If $1 / 6841 \mathrm{t}$ (scale 11 ) be converted into an infinite undecimal, prove that the 49,513th figure is 5 .

Times change, however, and the present Gazette again carries problems and solutions, the feature having been reintroduced in 1981.

Where the editor did not compromise was in the review section. The Gazette published between 50 and 80 reviews and short notices every year covering mathematical books at all levels. Greenstreet took the view that the ordinary school teacher had the right to know what was happening at the higher levels of his subject - wherever it was happening. Around $30 \%$ of all reviews were of foreign language publications, usually French or German. The importance Greenstreet attached to this work comes out in the number of reviews he himself wrote; for example between 1900 and 1906 his name appears against 191 of the 400 published reviews. What that meant in terms of workload can be imagined, but through it he created the Gazette's reputation as a review journal, not only with readers but, equally important, with publishers. E. H. Neville said of this '.. the review pages of [Greenstreet's] Gazette were admitted to be among the best in the world'.

At the heart of the Gazette, of course, were the longer articles, perhaps two or three in a typical number, and the shorter contributions called Mathematical Notes. The notes addressed many topics but in the early days there was a marked preponderance of elementary geometry with nearly half of all notes appearing before the First World War falling in this area. What the editor looked for in a note were 'shorter and more elegant methods than those in current textbooks'.

In 1906, in response to criticisms that the articles did not meet the needs of the average teacher, Greenstreet made an appeal for more pedagogical articles. This appeal was so successful that by 1909 there had been a significant shift in emphasis with over half the Gazette being occupied with educational material. Other features however, the reviews and the mathematical notes, enabled it to retain its character as a journal, and the Gazette never took on a'political' character in the reform movement.

Greenstreet was always alive to ways of making the journal more useful to its readers - in 1903 he started a Sale and Wanted corner, and in 1907 he 
began a regular Queries column, but this latter feature did not last beyond 1914. Correspondence was always welcomed, and information about the Association's library appeared from time to time and, inevitably, a scattering of obituaries. A small feature worthy of notice was called The Pillory, in which examples of bad examination questions could be held up for scorn the sort of thing that aroused the ire of correspondents is this question from a 1904 Board of Education examination.

The external measurements of a closed box are 36 inches, 2.2 feet, and 0.506 yards. Find the cubic space within if the wood of which it is made has a uniform thickness of one-tenth of a foot.

After the First World War the steam went out of the educational reform movement and the Association and its journal entered a more stable but less exciting era which really lasted until the late fifties when reform was again in the air. The war itself, however, hardly affected the Gazette directly; there was a small reduction in size, and post-war inflation led to price increases (three shillings by 1925). In 1917, with the introduction of Gleanings Far and Near to utilise spaces at the foot of a page, the last of the traditional features of the Gazette was in place, although the actual use of the title 'Gleanings' has died out in recent years. Readers may find Gleaning No. 14 to be particularly provocative. It is taken from De Morgan's writings:

' No doubt a student should have some training in the .... process

[completing the square]; but his ultimate method should be that

of remembering, once and for all the formula in the text.'

Although Greenstreet edited the Gazette until his death in 1930, the years from 1900 to 1914 were the decisive ones in which he steered the journal to success and so played a large part in creating a sense of community amongst British teachers of mathematics. No doubt many factors contributed to his success but perhaps the key lies in a private letter he wrote describing his teaching methods.

' The sole principles I kept in view were to create a love of mathematics for its own sake, and, as far as I could to keep the historical side of the subject to the front.'

Greenstreet was succeeded as editor by a young lecturer at Reading University, T. A. A. Broadbent. Broadbent (1903-1973), who went on to become professor at the Royal Naval College, Greenwich, held the editorship for 25 years. His task was not easy, for the journal had a 'momentum' of its own. Its very success as a review journal read by university mathematicians tended to pull it in the 'highbrow' direction, and there was nothing comparable to the educational ferment of the first decade of the century to act as stimulus for change. Broadbent was aware the Gazette was in danger of losing its 'elementary' feel, but as he often pointed out, an editor cannot publish articles which have not been written. Nevertheless the broad character of the Gazette was unchanged: letters, notes about the library and requests for teacher exchanges maintained for the 
reader the sense of being part of an active community. The publication of extended reports of discussions at the Annual Meetings still found a place. In 1938 the subject was 'Teaching the Complete Duffer' and B. L. Gimson of Bedales School opened the discussion in the historic spirit of the Association with the words 'I don't believe the complete duffer in mathematics exists'.

Broadbent was particularly concerned to maintain foreign contacts, especially with the French, believing it important 'to keep readers...in touch with teaching ideals and practice in other countries'. And in 1937 he mentions that the 'number of reviews of textbooks in French and German is increasing'. He even occasionally published articles and notes in French and German. The most frequent contributor of articles in French was V. Thé bault (1882-1960), a distinguished amateur mathematician. The coming of the Second World War cut the links with the Continent, whilst wartime austerity seriously affected the Gazette - whereas the 1939 volume ran to 500 pages the 1942 volume was only 250 pages. Keeping the Gazette alive through the difficult war years was perhaps Broadbent's most significant achievement, one that was all the more remarkable in the light of the disruption to his own circumstances brought about by war work.

Just before he relinquished the editorship Broadbent introduced Pseudaria, a feature originally suggested by A. P. Rollett, as a showcase of fallacies and pitfalls 'to put beginners on their guard'. Over 30 Pseudaria appeared until the item faded away in the early 1970s. As an example here is no. 8 from 1956, taken from an A-level answer:

$$
(x+3)(2-x)=4 \text {, therefore } x+3=4 \text { or } 2-x=4 \text {. }
$$

But this blunder actually gives the correct answers, and moreover, as E. A. Maxwell, the contributor, points out, 'every quadratic equation can be solved in this way' - there may, of course, have to be some preliminary rewriting! [4]

When, in 1956, R. L. Goodstein (1912-1985) took over as editor the second of the century's eras of educational reform was under way. The Association and its journal had to respond to the new developments in teaching and learning that were exciting the interest of more and more teachers. The existence of a vigorous new organisation, the future ATM, directly engaged in educational reform added to the challenge. The introduction by Goodstein in 1958 of Classroom Notes began the process of re-establishing the elementary nature of the journal and of encouraging more contributions from practising teachers. By 1974, when this feature was reabsorbed into the Mathematical Notes, it had become clear to readers that even the most elementary contribution would be considered. It was Classroom Note 171, from C. D. Langford, that produced the largest mailbag:

'... the twentieth power of any number which is not a multiple of 5 has tens and units digits either 01 or 76 . Proof, please ...'.

Which of the Gazette's hundreds of articles produced the most response? 
A candidate must be 'The Problem of A, B, C and D' by Sir Arthur Eddington. This dates from 1935 [5] (it was reprinted in the 400th number) and discusses the question:

'If $A, B, C$ and $D$ each speak the truth once in three times (independently), and $\mathrm{A}$ affirms that $\mathrm{B}$ denies that $\mathrm{C}$ declares that D is a liar, what is the probability that D was speaking the truth?'

E. A. Maxwell (d. 1988), who succeeded Goodstein as editor in 1962 was a Scot who spent his working life as a teacher at Queen's College, Cambridge. His many textbooks are models of clarity and above all usefulness and he endeavoured to stamp these qualities on the Gazette. His notes for contributors read:

'Articles may be at any level, with a preference for those that will help the teacher in the class-room. The work need not be new, though freshness of approach is desirable. There is no lower limit at the "elementary" end, but articles will not normally be accepted at the "advanced" end if the subject-matter goes beyond what a recent honours graduate may be expected to have met or if the language is not such as may be expected to be within the experience of readers, most of whom are teachers in the schools....'.

Typically during the fifties a single issue of the Gazette had about 80 pages of which perhaps 20 were taken up with reviews. During Maxwell's editorship the size crept up to 120 pages with between 30 and 40 pages of reviews. The look of the journal changed too when, in 1967, the cover was redesigned. The contents list was moved to the back cover and the Association's crest appeared on the front whilst the traditional grey was replaced with colour.

Maxwell, as much by his own example as anything else, established the principle 'that it was impossible for a contribution to be too elementary'. He particularly encouraged the young author, but at the same time his Gazette continued to attract contributions from leading mathematicians - the May 1968 number, for example, contains material from J. E. Littlewood, L. J. Mordell, and J. L. Synge.

The Centenary of the Association in 1971 saw further changes. Maxwell handed over the editorship to D. A. Quadling, and at the same time the Association began its second journal, Mathematics in School.

This new journal, which aimed to meet the needs of teachers of younger pupils, took some of the pressure off the Gazette. Quadling could reasonably focus on upper secondary and beginning college teaching, and could pass over to the sister journal many books that previously might have been reviewed in the Gazette. There was no change, however, in the 'elementary' nature of the journal, and Quadling expressed his criterion for publication in these words:

' To what extent will this help the reader to become a better teacher of mathematics - whether at school, college, or university?' 
In pursuit of this aim Quadling often collaborated with authors in several redrafts until he felt happy that the result was really accessible to the typical reader [6]. As the first editor since Greenstreet to have a school-teacher background he was well qualified to judge that accessibility.

The inflation of the 1970s led to the Gazette both costing more and being reduced in size. So that, whereas a single issue in 1970 contained 110 pages and cost less than 60p, in 1980 an issue cost $£ 2.50$ and contained fewer than 80 pages. Incidentally, it was in June 1980 that M. T. L. Bizley sent in what he claimed to be 'the most useless piece of information submitted' to the journal, namely:

' 1980 is rich in divisors, having 36 including 1 and 1980 itself.

We have to go back to 1800 to find a year with as many.'

Victor Bryant who became editor in 1980 paid tribute to his predecessor in these words:

'... the journal, under [Quadling's] guidance, has kept its sense of balance throughout almost a decade which has seen some considerable upheaval in the teaching of mathematics.'

This 'sense of balance' has not always pleased those who would like the Gazette to engage more directly with the 'political' aspects of educational reform. But on the whole, the Association's policy of addressing such issues through its committees and its Reports and not through its journal, has been beneficial. Each issue of the Gazette reminds teachers that they are more than functionaries in an educational system.

The Problem Corner is the most obvious legacy of Bryant's years as editor, but the raised profile of the Mathematical Notes is perhaps more important. Not only did these increase in number but they now appeared by title on the contents page. Where possible the editor collected notes on a single topic together thus enhancing the value of the single contribution. Bryant continued Quadling's 'interventionist' policy, rewriting material if necessary 'to make its relevance to teachers more clear' and to encourage more contributions from schoolteachers, and during his ten years as editor he saw his correspondence go up from two or three items a day to about a dozen a day [7].

In 1990 Nick MacKinnon became editor and his four years in the post saw a number of innovations - a glossy cover, three and not four issues a year, and a number of new features. Some of these features seem to have established themselves - the Student Problems, for example, and the very useful Other Journals section reporting articles of interest published elsewhere. The Stamp Corner has had to lapse as its author was committed to publishing a similar column elsewhere, whilst Mathematical People is perhaps in abeyance.

Criticisms have been heard of MacKinnon's encouragement of historical articles as if this were a new departure for the Gazette, whereas, in fact, it has always carried such articles right from its very first number. G. J. Whitrow, writing on the subject in the October 1932 number, begins 
'Glaisher, I believe, once said that no subject loses more than mathematics by any attempt to disassociate it from its history'.

Since 1894 the Gazette has played a uniquely creative role in the life of British mathematics. It has established two vital principles: that those who teach in the schools and those who teach and research in the universities are colleagues; and that every teacher of mathematics can be, and should be, active in mathematics at some level, and alive to new ideas in the subject. The robust structure that the journal has evolved will enable its present editor, Steve Abbott, and future editors to innovate without losing its substance, and we can have every confidence in its future.

\section{References}

1. A. W. Siddons, Math. Gaz. 20 (February 1936) pp. 7-26.

2. R. Levett, Nature 2 (26 May, 1870).

3. M. Price, Mathematics for the Multitude? The Mathematical Association (1994).

4. E. A. Maxwell, Math. Gaz. 40 (February 1956) p. 58.

5. A. S. Eddington, Math. Gaz. 19 (October 1935), pp. 256-257.

6. D. Quadling, personal communication.

7. V. Bryant, personal communication.

MIKE DAMPIER

Department of Mathematics and Computer Science, University of Leicester LEI 7RH

Roy Ashley was taught pure mathematics by 'Bish' Crockford and applied mathematics by Charles Wilding, the headmaster of Brentford Secondary Modern. He was the first boy from the school to proceed to university and, as one of the first group of male undergraduates at Royal Holloway College, was taught by Mary Bradburn. He completed his PGCE at Southampton University before starting as a teacher at St Bernadettes School in Bristol. In 1975 he founded the mathematics department at his present school, Wootton Upper School in Bedfordshire. For the MA, he has chaired the Head of Department subcommittee, served on both Council and Standing Committee and represented the MA on committees of the School's Council, the Royal Society, SCAA and the DfEE.

Steve Abbott received his BSc from Birmingham in 1980 and his MSc from the Open University in 1990. After teaching in Tipton and at Stockport College he became Head of Mathematics at Farlingaye High School, Woodbridge in 1990. He joined the Association in 1982 and began reviewing books for the Gazette in 1990 . He has served on various subcommittees of Teaching Committee and the BMO Committee. He enjoys reading elementary and expository mathematical articles, which is just as well as he has edited the Gazette since 1995. He also enjoys watching football, but supports Ipswich Town. 